\title{
An Epidemiological Study of Gammaglobulin Levels in Newborn Calves
}

\author{
P. DOBBELAAR, J.P.T.M. NOORDHUIZEN and K.A.S. VAN KEULEN \\ Faculteit de Diergeneeskunde, Rijksuniversiteit te Utrecht, Postbus 80.152, 3508 TD Utrecht \\ (The Netherlands)
}

(Accepted for publication 6 May 1987)

\begin{abstract}
Dobbelaar, P., Noordhuizen, J.P.T.M. and van Keulen, K.A.S., 1987. An epidemiological study of gammaglobulin levels in newborn calves. Prev. Vet. Med., 5: 51-62.

The effect of various factors on serum gammaglobulin concentration in newborn dairy calves was studied in 181 calves on six commercial farms. The refractometer test for monitoring colostrum management was found to be a reliable, rapid and practical method up to 6 days after birth. The three factors, time of first colostrum feeding, quantity of first colostrum intake and gammaglobulin concentration in first colostrum, explained $19.9 \%$ of the variation in serum gammaglobulin concentration. Time of milking, time of first colostrum intake and gammaglobulin concentration in first colostrum explained $21.0 \%$ of the variation in serum gammaglobulin concentration. Calves from first lactation cows showed lower serum gammaglobulin concentrations than calves of older cows.
\end{abstract}

\section{INTRODUCTION}

There are four major protein fractions in calf blood serum: the albumin and the alpha-, beta- and gammaglobulins (Borg and Frerking, 1982). Most of the immunoglobulins ( Ig) are in the gammaglobulin fraction. The increased total protein (TP) in blood of calves in the first week of life is mainly due to an increase in gammaglobulin level (Naylor and Kronfeld, 1977). In this period, albumin and alphaglobulins remain at a constant level and betaglobulins show only a slight increase (Breukink et al., 1974).

The literature provides abundant information on the major factors affecting the serum gammaglobulin levels in calves. Among these factors are the time, quantity and method of intake of the first colostrum fed (Barber, 1978; Stott et al., 1979; Borg and Frerking, 1982; von Eigenmann et al., 1983). The extent to which each factor contributes to the serum gammaglobulin level is, however, a matter of discussion (Bush et al., 1973; Stott et al., 1979).

Herds with a history of disease in their young stock require rapid Ig deter- 
mination methods for facilitation of disease prevention. Serum levels of gammaglobulins and total protein in young calves may be assessed by glutaraldehyde and refractometer tests, respectively, (McBeath et al., 1971; Naylor and Kronfeld, 1977; Frerking et al., 1980; van Keulen et al., 1984).

The objective of this study was to confirm the relationship between serum total protein (assessed by refractometer test) and serum gammaglobulin level in individual calves on commercial dairy farms. Additional studies were performed in order to explain differences in serum gammaglobulin levels caused by factors influencing colostrum supply to individual calves.

\section{MATERIAL AND METHODS}

Calves

Calves on six commercial dairy farms in the area of the Ambulatory Clinic of the Veterinary School of Utrecht were used in the study. They were born in February, March and April. A questionnaire on colostrum feeding and rearing method, birth history and health status was completed for each calf, together with data on the dam. Major items from the questionnaire are listed in Table I. Calves with missing data, e.g. suckled calves, were omitted from the analysis. Major characteristics for the herds, colostrum feeding methods and mean serum and colostrum gammaglobulin concentration per herd are presented in Table II.

Blood sampling and serum total protein level

Plain blood samples were obtained from all calves (jugular vein) before Day 6 after birth. Serum was collected by centrifugation. Total protein concentration in serum was assessed by means of the refractometer test, whereafter the samples were stored at $-15^{\circ} \mathrm{C}$ to determine total protein and gammaglobulin concentrations by the biuret method and electrophoresis, respectively.

\section{Refractometer}

Total protein concentration was determined by the refractometer test (Serum Protein Refractometer, ATAGO, Model 310) according to the method described by Reid and Martinez (1975). The refractometer was gauged using distilled water. Total protein concentrations could be read from a calibration in grams per decilitre, and for our purposes were converted to grams per litre. The prism was cleaned with distilled water after every reading. 


\section{TABLE I}

Variables taken from the questionnaire, groups per variable, mean serum gammaglobulin concentration, number of calves per variable and statistical significance of difference between-group means

\begin{tabular}{|c|c|c|c|}
\hline Variables from the questionnaire (groups) & $\begin{array}{l}\text { Mean serum } \\
(c=\text { colostrum }) \\
\text { gammaglobulin } \\
\text { concentration } \\
\left(\mathrm{g} \mathrm{l}^{-1}\right) \pm \text { s.d. }\end{array}$ & $\begin{array}{l}\text { Number } \\
\text { of calves }\end{array}$ & STAT (P) \\
\hline $\begin{array}{l}\text { Day of } 1 \text { st blood sample } \\
\text { (Day } 1 \text { to Day } 6 \text { ) }\end{array}$ & $14.4 \pm 8.5$ & 172 & n.s. \\
\hline $\begin{array}{l}\text { Time of feeding 1st colostrum } \\
\left(0-\frac{1}{2}, \frac{1}{2}-1 \frac{1}{2}, 1 \frac{1}{2}-3,3-5,>5 \text { h after birth }\right)\end{array}$ & $14.9 \pm 8.7$ & 150 & ${ }^{* * *}(P<0.001)$ \\
\hline $\begin{array}{l}\text { Quantity of 1st day colostrum } \\
(0.3-0.5,0.6-1.0,1.1-1.5,1.6-2.0,>2.0)\end{array}$ & $14.9 \pm 8.7$ & 150 & $*(P<0.03)$ \\
\hline $\begin{array}{l}\text { Total quantity of } 1 \text { st day colostrum } \\
(2-3,4,5,6,71)\end{array}$ & $15.4 \pm 8.7$ & 140 & $* *(P<0.006)$ \\
\hline Parity (1-9) & $14.7 \pm 8.7$ & 155 & $* *(P<0.01)$ \\
\hline $\begin{array}{l}\text { Calving history of the dam (spontaneous, } \\
\text { assisted, difficult, twin, caesarean) }\end{array}$ & - & & n.s. $(P=0.7)$ \\
\hline Sex of the calf (male, female) & $\begin{array}{l}14.1 \pm 7.8 \text { (male) } \\
14.5 \pm 9.3 \text { (female) }\end{array}$ & $\begin{array}{l}80 \\
90\end{array}$ & n.s. $(P=0.8)$ \\
\hline $\begin{array}{l}\text { Body weight of the calf on Day } 3(<35, \\
36-40,>40 \mathrm{~kg})\end{array}$ & - & & n.s. $(P=0.5)$ \\
\hline $\begin{array}{l}\text { Health status of the dam } \\
\text { (with/without clinical mastitis at calving) }\end{array}$ & $\begin{array}{l}14.1 \pm 8.7 \text { (mastitis) } \\
14.5 \pm 8.6 \text { (no) }\end{array}$ & $\begin{array}{r}24 \\
147\end{array}$ & n.s. \\
\hline $\begin{array}{l}\text { Health status of the calf } \\
\text { (with/without clinical diarrhoea on day } 3 \text { ) }\end{array}$ & $\begin{array}{l}14.4 \pm 8.6 \text { (diarrhoea) } \\
14.4 \pm 8.0 \text { (no) }\end{array}$ & $\begin{array}{r}164 \\
10\end{array}$ & n.s. $(P=0.91)$ \\
\hline $\begin{array}{l}\text { Person who supplies colostrum to the calf } \\
\text { (farmer; other e.g. wife, child) }\end{array}$ & $\begin{array}{l}15.9 \pm 8.7 \text { (farmer) } \\
10.7 \pm 7.4 \text { (other) }\end{array}$ & $\begin{array}{r}121 \\
28\end{array}$ & ${ }^{* *}(P<0.01)$ \\
\hline $\begin{array}{l}\text { Method of feeding colostrum (bucket, } \\
\text { bucket }+ \text { nipple, bottle + nipple, suckling } \\
\text { cow) }\end{array}$ & - & & ${ }^{* *}(P<0.01)$ \\
\hline $\begin{array}{l}\text { Length of dry period of the dam } \\
(25-50,51-65,66-80,>80 \text { days })\end{array}$ & $106 \pm 32(c)$ & 96 & n.s. \\
\hline
\end{tabular}

STAT $=$ Statistical significance of differences between group means.

n.s. $=$ not significant; ${ }^{*, * * * * * *}=$ significant. 
TABLE II

Major characteristics of the dairy herds, colostrum feeding method, and serum and colostrum gammaglobulin concentration as group mean per herd

\begin{tabular}{|c|c|c|c|c|c|c|c|c|c|c|}
\hline \multirow[t]{2}{*}{ Herd } & \multirow{2}{*}{$\begin{array}{l}\text { Average } \\
\text { No. of } \\
\text { cows }\end{array}$} & \multirow[t]{2}{*}{ Breed' } & \multirow{2}{*}{$\begin{array}{l}\text { Housing } \\
\text { system }\end{array}$} & \multicolumn{5}{|c|}{ Calves per feeding method first colostrum } & \multirow{2}{*}{$\begin{array}{l}\text { Serum } \\
\text { gamma- } \\
\text { globulin } \\
\text { conc. } \\
\left(\mathrm{gl}^{-1}\right) \\
X \pm \text { s.d. }\end{array}$} & \multirow{2}{*}{$\begin{array}{l}\text { Colostrum } \\
\text { gamma- } \\
\text { globulin } \\
\text { conc. } \\
\left(\mathrm{g} \mathrm{l}^{-1}\right) \\
X \pm \text { s.d. }\end{array}$} \\
\hline & & & & $\begin{array}{l}\text { Bottle } \\
\text { nipple }\end{array}$ & $\begin{array}{l}\text { Bucket } \\
\text { nipple }\end{array}$ & Bucket & $\begin{array}{l}\text { Calf } \\
\text { suckling }\end{array}$ & Unknown & & \\
\hline 1 & 80 & $\mathrm{HF}$ & $\mathrm{C}$ & & & 24 & & & $7.2 \pm 3.8$ & $102 \pm 34$ \\
\hline 2 & 80 & $\mathrm{HF}$ & $\mathrm{T}$ & & 41 & 2 & & & $17.5 \pm 9.2$ & $93 \pm 31$ \\
\hline 3 & 85 & MRY & $\mathrm{C}$ & 39 & & & & 2 & $18.3 \pm 7.4$ & $116 \pm 30$ \\
\hline 4 & 90 & $\mathrm{HF}$ & $\mathrm{C}$ & & 1 & 10 & & & $13.2 \pm 5.7$ & $112 \pm 26$ \\
\hline 5 & 100 & $\mathrm{HF}$ & $\mathrm{C}$ & & 20 & 7 & 1 & & $16.8 \pm 8.1$ & $118 \pm 21$ \\
\hline 6 & 90 & $\mathrm{FH}$ & $\mathrm{C}$ & & & 13 & 18 & & $9.2 \pm 6.8$ & $96 \pm 24$ \\
\hline
\end{tabular}

${ }^{1} \mathrm{HF}=$ Holstein - Friesian crossbreed; MRY = Dutch Red Breed; FH = Dutch Friesian Breed.

${ }^{2} \mathrm{C}=$ cubicle housing; $\mathrm{T}=$ tied housing.

Total protein and gammaglobulin concentration in serum samples

The concentration of total protein was measured using the biuret method, while the protein spectrum was determined after electrophoresis on cellulose acetate foil and Ponceau $S$ staining. The fractions were measured in percentages using a densito-meter (Densito-meter, VITATRON) technique. Gammaglobulin concentrations were calculated from serum protein concentration and the gammaglobulin percentages.

\section{Colostrum samples}

The quantity of first colostrum intake was measured by the farmer with a calibrated bucket or bottle.

Samples were taken from the first colostrum fed to calves and were stored at $-15^{\circ} \mathrm{C}$ by the farmer. A total of 135 samples were available for measurement of gammaglobulin concentration.

\section{Statistical analyses}

Data were analyzed using the Statistical Package for the Social Sciences, SPSS, (Nie et al., 1975). They included primary calculations, such as correlation and regression coefficients between variables, and $a t$-test for differences between group means (Table I).

A multiple regression programme was used because several factors might influence serum and colostrum gammaglobulin concentrations and all included variables (except herd effect) were measured at ratio level. A forward-stepwise 
TABLE III

Relationship between serum gammaglobulin level (determined by total protein and spectrum) and serum total protein level (determined by refractometer) in blood of calves between $24 \mathrm{~h}$ and 6 days after birth

\begin{tabular}{llll}
\hline $\begin{array}{l}\text { Sampling day } \\
\text { after birth }\end{array}$ & $\begin{array}{l}\text { Correlation } \\
\text { coefficient }\end{array}$ & $P$ & $\begin{array}{l}\text { No. of } \\
\text { samples }\end{array}$ \\
\hline 1 & 0.82 & 0.001 & 60 \\
2 & 0.60 & 0.001 & 45 \\
3 & 0.77 & 0.001 & 34 \\
4 & 0.74 & 0.001 & 22 \\
5 & 0.83 & 0.005 & 9 \\
6 & - & - & 2 \\
\hline
\end{tabular}

procedure was followed. However, other combinations of the variables were also tested to determine which combination would yield the best prediction of the dependent variable (gammaglobulin level in first colostrum and in serum, respectively). Only those variables which appeared to be significantly correlated with the dependent variables and to which any relevance could be attributed were included in the model. No observations were made on herd level in this study; herd effect can only be estimated retrospectively e.g. by using dummy variables in a multiple regression model.

\section{RESULTS}

\section{Comparison of the methods of measuring gammaglobulin}

The relationship between serum total protein (assessed by refractometer test) and serum gammaglobulin concentration (determined by serum total protein and serum protein spectrum ) is presented in Table III and Fig. 1. This relationship may be expressed as

$Y=0.6 X-18.6$

where $Y=$ serum gammaglobulin concentation $\left(\mathrm{g} \mathrm{l}^{-1}\right)$ and $X=$ serum total protein concentration $\left(\mathrm{gl}^{-1}\right)$ by the refractometer test. The correlation is high and statistically significant (mean value 0.74 ) and remains on a high level from Day 1 to Day 6 (Table III).

\section{Epidemiological study}

General aspects

Sut:stantial differences in mean serum gammaglobulin levels could be noted between farms (Table II). The lowest value was $7.2 \mathrm{~g} \mathrm{l}^{-1}$ and the highest was $18.3 \mathrm{~g} \mathrm{l}^{-1}$. 


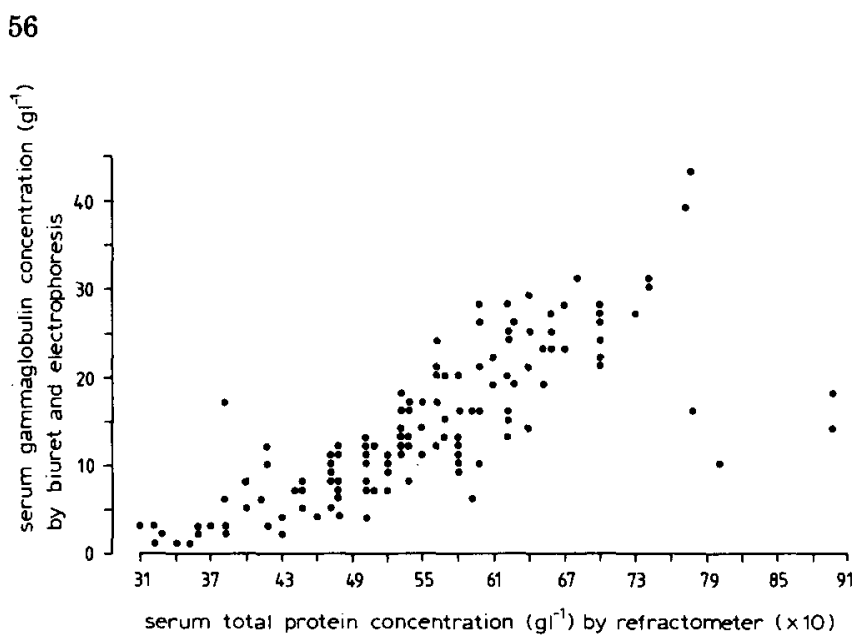

Fig. 1. The relationship between serum total protein concentration determined by the refractometer and serum gammaglobulin concentration determined by the biuret method and electrophoresis.

Serum gammaglobulin levels were highest in calves which showed the greatest colostrum intake on the first day after birth. For intakes of 2-3 and 71 they were 13.4 and $20.8 \mathrm{~g} \mathrm{l}^{-1}$, respectively.

Calves from first lactation cows showed an average serum gammaglobulin level of $10.0 \mathrm{~g} \mathrm{l}^{-1}$, while this value was significantly higher $\left(15.8 \mathrm{~g} \mathrm{l}^{-1}\right)$ for calves of older cows.

The interval between calving and first milking was equal for both first lactation and older cows. However, the first colostrum was usually ingested $1 \mathrm{~h}$ later by calves from first lactation cows compared with calves from older cows.

The quantity of first colostrum fed differed significantly between parities, with a mean of 1.21 for calves from parity 1 and 1.51 for calves from higher parity cows.

Assistance at calving was provided in 26 of 37 first lactation cows and in 46 of 125 older cows.

No substantial differences in gammaglobulin levels of colostrum from first lactation versus older cows were detected; the levels were 101 and $105 \mathrm{~g} \mathrm{l}^{-1}$, respectively. Between farms the following differences were noted: the lowest mean was $93 \mathrm{~g} \mathrm{l}^{-1}$ and the highest was $118 \mathrm{~g} \mathrm{l}^{-1}$. Within each farm, wide variations in colostrum gammaglobulin levels occurred between cows.

\section{Correlation coefficients}

The correlation matrix including the variables under study is presented in Table IV.

The gammaglobulin concentration in first colostrum fed was significantly correlated with parity $(P=0.014)$ and quantity of first colostrum intake $(P=0.033)$. Time of milking first colostrum appeared not to be correlated with gammaglobulin concentration in first colostrum fed. The correlation between 
TABLE IV

Pearson correlation coefficients for the variables in the study

\begin{tabular}{lccc}
\hline & Parity & $\begin{array}{l}\text { Gammaglobulin } \\
\text { concentration in } \\
\text { first colostrum fed }\end{array}$ & $\begin{array}{l}\text { Serum } \\
\text { gammaglobulin } \\
\text { concentration }\end{array}$ \\
\hline Length of dry period & 0.11 & -0.02 & 0.04 \\
Parity & 1.0 & $0.20^{*}$ & 0.23 \\
Time of milking first colostrum & $0.19^{*}$ & -0.04 & $0.32^{*}$ \\
Time of feeding first colostrum & $-0.21^{*}$ & -0.01 & $-0.27^{*}$ \\
Quantity of first colostrum fed & $0.17^{*}$ & $-0.17^{*}$ & $0.15^{*}$ \\
$\begin{array}{l}\text { Total quantity of colostrum fed } \\
\text { during first 24 h after birth }\end{array}$ & $0.17^{*}$ & -0.03 & $0.21^{*}$ \\
$\begin{array}{l}\text { Gammaglobulin concentration } \\
\text { in first colostrum fed }\end{array}$ & $0.20^{*}$ & 1.0 & $0.24^{*}$ \\
\hline
\end{tabular}

${ }^{*} P<0.05$.

time of milking first colostrum and time of feeding first colostrum was 0.55 and indicates that first colostrum is not always fed to calves immediately after milking.

Serum gammaglobulin concentration in this material is significantly correlated ( see Table IV) with parity, time of milking first colostrum, time of feeding first colostrum, quantity of first colostrum fed, total quantity of colostrum fed during first $24 \mathrm{~h}$ after birth and gammaglobulin concentration in first colostrum fed. Parity was significantly but weakly correlated with all other five variables. Each of these five variables was also significantly correlated with serum gammaglobulin concentration. For that reason, parity was excluded as a predictor from the multiple regression analysis model (see Multiple regression analysis model). The five remaining variables were included in the multiple regression analysis model to predict serum gammaglobulin concentration. Time of feeding first colostrum was negatively correlated with parity, while the time of milking first colostrum was positively correlated with parity (Table IV).

\section{Multiple regression analysis model}

Colostrum gammaglobulin concentration. Quantity of first colostrum fed and parity accounted for only $10.6 \%$ of the variation in colostrum gammaglobulin concentration (Table V). Other factors appeared to affect colostrum quality but could not be detected in this study.

Serum gammaglobulin concentration. In the forward-stepwise procedure, where all five independent variables (see Correlation coefficients) were included, time 


\section{TABLE V}

Regression equation for prediction of colostrum gammaglobulin concentration by a combination of two variables, and the $R^{2}$ of the gammaglobulin concentration in the first fed colostrum by the forward stepwise regression analysis

Colostrum gammaglobulin concentration $=c+b_{1} X_{1}+b_{2} X_{2}$

$$
\text { where } \begin{aligned}
c & =112.97 X_{1}=\text { parity } \\
b_{1} & =3.89 X_{2}=\text { quantity of first colostrum fed } \\
b_{2} & =-1.27
\end{aligned}
$$

\begin{tabular}{llcl}
\hline Step & Variable & $\begin{array}{l}R^{2} \\
(\%)\end{array}$ & $P$ \\
\hline 1 & Parity & 5 & 0.103 \\
2 & Quantity first colostrum fed & 10.6 & 0.077
\end{tabular}

of milking first colostrum and total quantity of colostrum fed during the first $24 \mathrm{~h}$ after birth did not appear to contribute significantly to the proportion of variation accounted for by the variables $\left(R^{2}=0.21\right)$. Reduction of the number of these variables from five to three yielded an $R^{2}$ of 0.199 (Table VI, eqn. 1).

In another model where time of milking first colostrum was forced to enter in the first step and the other four variables were entered via forward-stepwise inclusion, only quantity of first colostrum fed and gammaglobulin concentration in first colostrum fed contributed significantly to the proportion of variation accounted for by the variables $\left(R^{2}=0.21\right)$. Reduction of the number of variables from five to three yielded an $R^{2}$ of 0.21 (Table VI, eqn. 2).

In situations where the colostrum gammaglobulin concentration is unknown, the serum gammaglobulin concentration may be estimated by two combinations of predictors in an equation. However, these methods only yield $R^{2}$ values of 9 and $10.9 \%$, respectively.

\section{DISCUSSION}

The correlation coefficient found in this study for the association between serum total protein and serum gammaglobulin concentration agrees with results found by other workers (Bush et al., 1973; van Keulen et al., 1984). Ristedt (1980) indicated that a high correlation coefficient between gammaglobulin concentration (nephelometric method) and serum total protein (by refractometer test) exists only $10-20 \mathrm{~h}$ after the first colostrum feeding. ThodeJensen (1978) found a rather small correlation coefficient at 2 weeks after birth.

From this study it appears that a high correlation coefficient may be found during the first 5 days of life. Under the field conditions of this study, serum 


\section{TABLE VI}

Regression equation for prediction of serum gammaglobulin concentration using a combination of three variables, and the respective $R^{2}$ of serum gammaglobulin concentration by the stepwise regression analysis procedure (maximum of three steps; time of milking first colostrum was forced as variable into the first step in the second equation)

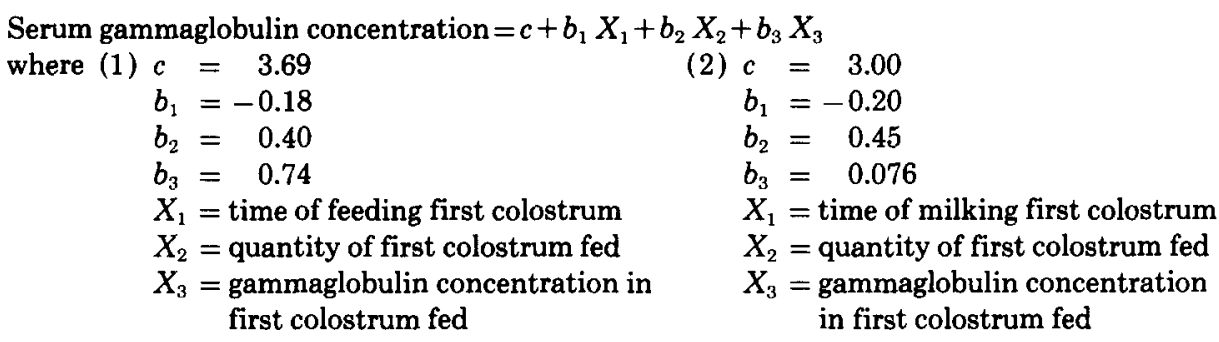

\begin{tabular}{lllllll}
\hline Step & Equation & Variable & $\begin{array}{l}R^{2}(1) \\
(\%)\end{array}$ & $\begin{array}{l}R^{2}(2) \\
(\%)\end{array}$ & $P(1)$ & $P(2)$ \\
\hline 1 & $(1)$ & $\begin{array}{l}\text { Time of feeding first colostrum } \\
\text { Time of milking first colostrum }\end{array}$ & 9.5 & & 0.02 & \\
2 & $(2)$ & $\begin{array}{l}\text { Quantity of first colostrum fed } \\
\text { Quantity of first colostrum fed }\end{array}$ & 13.8 & 9 & 0.11 & 0.03 \\
3 & $(1)$ & $\begin{array}{l}\text { Gammaglobulin concentration } \\
\text { in first colostrum fed } \\
\text { Gammaglobulin concentration } \\
\text { in first colostrum fed }\end{array}$ & 19.9 & & 0.05 & \\
\hline
\end{tabular}

$R^{2}=$ Proportion of variation explained by the variables in the respective steps of the procedure.

$P=$ Significance of entering the variables in the procedure in that step.

gammaglobulin concentrations in calves up to 6 days old may be checked by a refractometer test on regular herd visits.

The differences in mean serum gammaglobulin concentration between herds are substantial (Table II). The lowest values were constantly observed in herds where the method of feeding was with a bucket without a nipple, where the first colostrum was fed in low quantity and at a long time interval after birth.

In 60 of the 174 calves ( $34.5 \%)$ the serum total protein determined by refractometer test was $<50 \mathrm{~g} \mathrm{l}^{-1}$; in 39 calves $(22.4 \%)$ this concentration was below $45 \mathrm{~g} \mathrm{l}^{-1}$. This value should be above $55 \mathrm{~g} \mathrm{l}^{-1}$ for an acceptable health risk level for calves passing through market places (Braun and Tennant, 1983). In this study only 84 of the 174 calves (48.2\%) achieved this level. Barber (1978) indicated that serum gammaglobulin concentration in calves was less important on farms where infection pressure was low. Calves with low serum gammaglobulin concentrations could be reared without any problem. This agrees with our findings on one farm where 24 of the 33 calves had a (refractometer 
measured) serum total protein concentration of $<50 \mathrm{~g}^{-1}$, and no calf diarrhoea occurred on this farm. Clinical diarrhoea on Day 3 did not significantly affect serum gammaglobulin concentration in our study (Table I).

The difference between serum gammaglobulin concentration in calves of first lactation and older cows indicated that in our situation calves of the former group had a higher risk of disease. The lower levels in these calves may be partly explained by differences in both time of interval between birth and first colostrum feeding, and in total quantity fed during the first day. No differences were found in gammaglobulin concentration in colostrum between first lactation and older cows. Luetgebrune (1982) indicated that a lower vitality in these calves after a stressful birth may explain the delayed intake of less colostrum. In our study it appeared that calving assistance was provided in nearly twice as many cases in first lactation than in older cows. Calving history of the dam did not significantly affect serum gammaglobulin concentration in calves (Table I).

Differences in serum gammaglobulin concentration between both groups of persons feeding the calves (farmer versus other) were statistically significant (Table I). Colostrum feeding by the farmer resulted in higher concentrations. However, the interval from birth to first feeding was significantly shorter for farmers and is a confounder in that respect.

Gammaglobulin concentration in the colostrum was not significantly correlated with the time of the first colostrum feeding in our study $(-0.002$, $P=049$ ) and this finding disagrees with results reported by Pivont et al. (1984): $0.666, P=0.01$. Colostrum gammaglobulin concentration was negatively correlated with the quantity of first colostrum fed in our study $(-0.1704$, $P=0.033)$. This was in agreement with the results reported by Pivont et al. (1984). The differences noted could not be explained. In our study, serum gammaglobulin concentration was significantly but weakly correlated with time of feeding first colostrum $(-0.274)$, quantity of first colostrum fed $(0.151)$, total quantity of colostrum fed in the first $24 \mathrm{~h}$ after birth $(0.214)$, and quantity of first colostrum fed (0.237). Pivont et al. (1984) found no significant correlation between serum gammaglobulin concentration and time of feeding first colostrum, quantity of first colostrum intake and total quantity of colostrum intake during first $24 \mathrm{~h}$ after birth, and only a significant correlation with gammaglobulin concentration in first colostrum fed. These differences in results cannot be explained by differences in analysis procedures alone.

Significant differences between feeding methods occurred (Table I). Nipple feeding (with bucket or bottle) resulted in higher serum gammaglobulin concentrations than did other methods. However, this could be an expression of herd effect since the feeding method is usually consistent within a herd. Effects of feeding method for first colostrum could be confounded with herd effect. The fact that more calves originated from one farm and observations per farm 
were thus correlated may point to a herd effect as well. However, observations were made on individual calf level in this study.

Results from the multiple regression analyses indicate to what extent the various equations explain the variation in serum gammaglobulin concentration. The final two equations (Table VI) explain 19.9 and $21 \%$ of the variation in serum gammaglobulin concentration in calves born on the commercial dairy herds in this study. The $R^{2}$ values detected in all four multiple regression equations appeared to range from 9 to $21 \%$. The two regression equations (a) and (b), which exclude colostrum gammaglobulin concentration as a variable, yield an $R^{2}$ value of 9 and $10.9 \%$.

Serum gammaglobulin concentration $=c+b_{1} X_{1}+b_{2} X_{2}$

where (a) $X_{1}=$ time feeding first colostrum, $X_{2}=$ quantity first colostrum, $c=15.11, b_{1}=-0.169, b_{2}=0.165$ and $R^{2}=9 \%$; (b) $X_{1}=$ time feeding first colostrum, $X_{2}=$ total quantity 1 st day colostrum, $c=10.18, b_{1}=0.15, b_{2}=1.48$ and $R^{2}=10.9 \%$.

These $R^{2}$ values are rather low, pointing to the importance of including colostrum gammaglobulin concentration as a variable in the study, which allows better prediction of serum gammaglobulin concentration. Total quantity of colostrum fed during the first $24 \mathrm{~h}$ after birth appeared to be less important in this study. Under field conditions Geene (1984) found the same effect. Other factors affecting serum gammaglobulin concentration were not detected and require further study.

A final conclusion of this study is that the refractometer test is a practical and useful method for the assessment of serum gammaglobulin concentration in newborn calves under Dutch dairy farming conditions.

\section{ACKNOWLEDGEMENTS}

The authors gratefully acknowledge the cooperation of the six dairy farmers in this study and Dr. J.A.J. Faber for statistical analysis and assistance.

\section{REFERENCES}

Barber, D.M.L., 1978. Serum immuno globulin status of purchased calves: An unreliable guide to viability and performance. Vet. Rec., 102: 418-420.

Binder, A., 1983. Der Einfluss verschiedener Tränkeverfahren auf den Immunglobulingehalt des Blutserums neugeborener Kälber. Ph.D. Thesis, Tierärtzl. Hochschule, Hannover, 92 pp. In German.

Borg, L. and Frerking, H., 1982. Erkenntnisse bei der Immunglobulinbestimming im Serum kranker Kälber. Tierärtzl. Umschau., 7: 488-489. In German.

Braun, R.K. and Tennant, B.C., 1983. The relationship of serum gammaglobulin levels of assembled neonatal calves to mortality caused by enteric diseases. Agripractice, 4: 14-24.

Breukink, H.J., Wensing, Th. and Schotman, A.J.H., 1974. Changes in blood components of veal calves during a rearing period of 18 weeks. Tijdschr. Diergeneeskd., 23: 1219-1234. In Dutch. 
Bush, L.J., Mungle, M.B., Corley, L.D. and Adams, G.D., 1973. Factors affecting absorption of immunoglobulins by newborn dairy calves. J. Dairy Sci., 56: 313-380.

Frerking, H., von Henkel, E. and Schwartz, E., 1980. Zur Brauchbarkeit der Refractometrie als indirekte Methode für Bestimming der Immunitätslage bei jungen Kälbern. Blauen Hefte., 62: 88-72.

Geene, J.J., 1984. Colostrum en Immuniteit. Mogelijke factoren die de immuunstatus van het jonge kalf beinvloeden. Ph.D. Thesis, State University of Utrecht, The Netherlands, $203 \mathrm{pp}$. In Dutch.

Luetgebrune, K., 1982. Untersuchungen über die Kolostrumaufnahme und die Immunglobulinabsorption bei asphyktischen und lebensfrische Kälbern. $\mathrm{Ph}$.D. Thesis, Tierärtzl. Hochschule, Hannover, 75 pp. In German.

McBeath, D.G., Penhale, W.J. and Logan, E.F., 1971. An examination of the influence of husbandry on the plasma immunoglobulin level of the newborn calf, using a rapid refractometer test for assessing immunoglobulin content. Vet. Rec., 88: 266-270.

Naylor, J.M. and Kronefeld, D.S., 1977. Refractometry as a measure of the immunoglobulin status of the newborn dairy calf: comparison with the zinc sulphate turbidity test and single radial immunodiffusion. Am. J. Vet. Res., 1331-1334.

Nie, N.H., Hull, C.H., Jenking, J.G., Steinbrenner, K. and Bent, D.H., 1973. Statistical Package for the Social Sciences. 2nd edn. McGraw-Hill Book Company, New York, NY, 675 pp.

Pivont, P., Gregoire, R. and Antoine, H., 1984. Investigation on farmer's colostrum feeding methods: habits affecting colostral status in neonatal calves. Ann. Rech. Vét., 15 (4): 509-513.

Reid, J.F.S. and Martinez, A.A., 1975. A modified refractometer method as practical aid to the epidemiological investigation of disease in the neonatal ruminant. Vet. Rec., 69: 177-179.

Ristedt, H., 1980. Untersuchungen uiber den Immunstatus von Kälbern in der drei ersten Lebenstagen mit Hilfe der Nephelometrie, der Elektroforese, der Refractometrie und die Biuretereaktion. Ph.D. Thesis, Tierärtzl. Hochchule, Hannover, 85 pp. In German.

Stott, G.H., Marx, D.B., Menefee, B.E. and Nightengale, G.T., 1979. Colostral immunoglobulin transfer in calves. III. Amount of absorption. J. Dairy Sci., 62: 1902-1907.

Thode Jensen, P., 1978. Quantitative studies on immunoglobulins, albumin and total protein in serum from young normal calves. Nord. Vetinearmed., 30: 145-154.

Van Keulen, K.A.S., Dobbelaar, P., Noordhuizen, J.P.T.M., Schwering, C. and Wensing, Th., 1984. Een onderzoek naar een aantal aspecten van de biestverstrekking op melkveebedrijven en de bruikbaarheid van de glutaaraldehydetest bij de beoordeling van de biestverstrekking. Tijdschr. Diergeneeskd., 109: 605-611.

Von Eigenmann, U.J.E., Zaremba, W., Luetgebrune, K. and Grunert, E., 1983. Untersuchungen über die Kolostrumaufnahme und die Immunglobulinabsorption bei Kälbern mit und ohne Geburtsazidose. Berl. Münch. Tierärtzl. Wschr., 96: 109-113. 